Please do not remove this page

RMIT

UNIVERSITY

\title{
Youth housing workers and housing affordability: Living on struggle street
}

Emslie, Michael

https://researchrepository.rmit.edu.au/esploro/outputs/9921858668301341/filesAndLinks?institution=61RMIT_INST\&index=null

Emslie, M. (2011). Youth housing workers and housing affordability: Living on struggle street. Australian Social Work, 64(3), 361-376. https://doi.org/10.1080/0312407X.2011.597411

Document Version: Published Version

Published Version: https://doi.org/10.1080/0312407X.2011.597411

Repository homepage: https://researchrepository.rmit.edu.au

(C) 2011 Australian Association of Social Workers

Downloaded On 2023/04/26 12:49:28 +1000

Please do not remove this page 
Thank you for downloading this document from the RMIT Research Repository.

The RMIT Research Repository is an open access database showcasing the research outputs of RMIT University researchers.

RMIT Research Repository: http://researchbank.rmit.edu.aul

\section{Citation:}

Emslie, M 2011, 'Youth housing workers and housing affordability: Living on struggle street', Australian Social Work, vol. 64, no. 3, pp. 361-376.

See this record in the RMIT Research Repository at:

https://researchbank.rmit.edu.au/view/rmit:12382

Version: Published Version

Copyright Statement:

(C) 2011 Australian Association of Social Workers

\section{Link to Published Version:}

http://dx.doi.org/10.1080/0312407X.2011.597411 


\section{Due Diligence Record Log}

вм No. n2006027322 PID No. 12382

Citation Emslie, M 2011, 'Youth housing workers and housing affordability: Living on struggle street', Australian Social Work, vol. 64, no. 3, pp. 361-376.

1. Author Deposit Agreement [ADA]

Or Deposit Agreement [ADA]
\begin{tabular}{|l|l|}
\hline Author Name & eMail Address \\
\hline Michael Emslie & michael.emslie@rmit.edu.au \\
\hline & \\
\hline & \\
\hline
\end{tabular}

\begin{tabular}{|l|l|} 
Date & \\
\hline & \\
\hline & \\
\hline & \\
\hline
\end{tabular}

$\mid$

Notes

\begin{tabular}{|l|l|l|}
\hline Initials & \multicolumn{1}{l}{ ADA Signed } & Date Received \\
\hline AR & Yes & $14 / 03 / 2019$ \\
\hline & & \\
\hline & & \\
\hline
\end{tabular}

Notes

2. Hosting Permission Request [HPR]

Name/Organisation

Mail/URL Address

Date

\begin{tabular}{|l|l|}
\hline & \\
\hline & \\
\hline & \\
\hline & \\
\hline & \\
\hline
\end{tabular}

Notes Following guidelines from Routledge self-archiving embargo period has lapsed, so uploading without contacting publisher.

Sent From

\begin{tabular}{|l} 
Notes \\
\hline
\end{tabular}

Initials

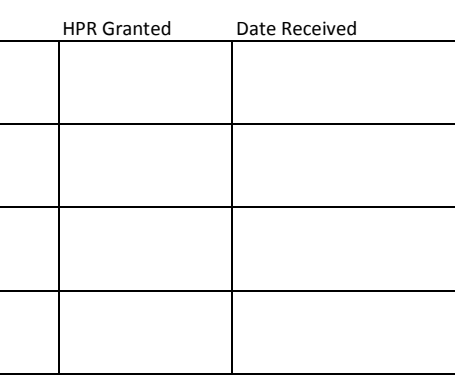

3. Hosting Policy Request

\begin{tabular}{|l|l|l|l|l|l|l|l|}
\hline \\
\hline
\end{tabular}

Notes 


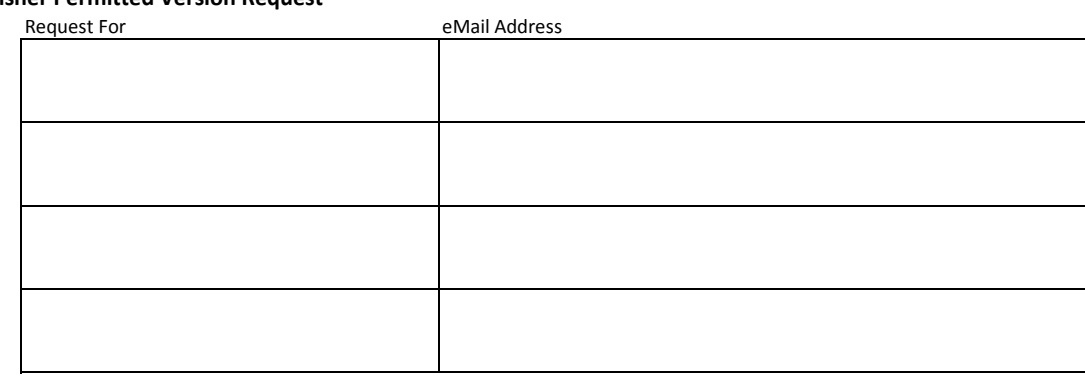

Notes

\begin{tabular}{|l|l|l|l|l|l|}
\hline & Sonte & Notes & & & \\
& & & Ritials & Resose Received Date Received \\
& & & & & \\
\hline & & & & & \\
\hline & & & & & \\
\hline
\end{tabular}

5. System Check: Research Master [RM] / RMIT Research Repository [RRR]

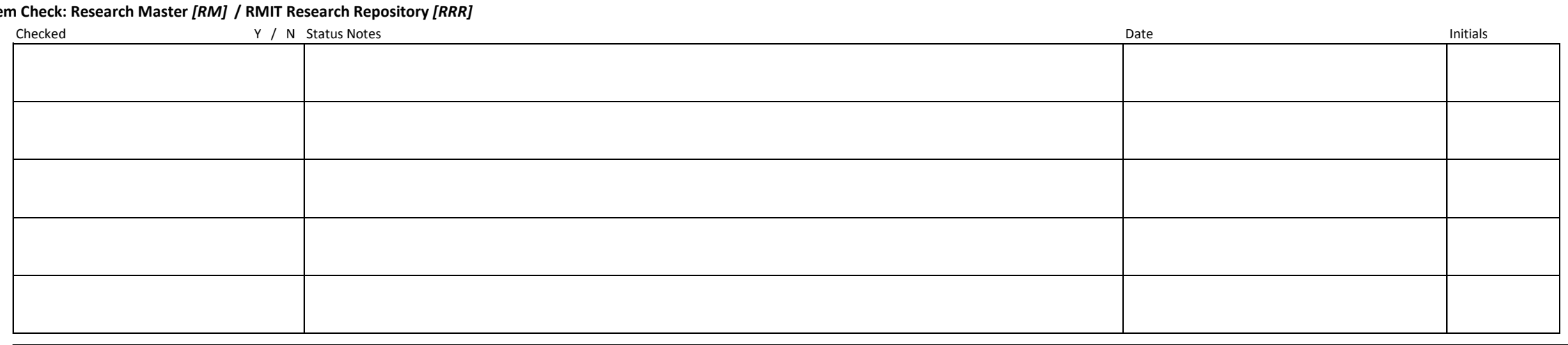

Notes 


\title{
Emslie, M. 2011, 'Youth housing workers and housing affordability: Living on struggle street', Australian Social Work, vol. 64, no. 3, pp. 361-376.
}

\begin{abstract}
This article argues youth housing workers in Victoria, Australia, are vulnerable to housing affordability problems and a reason for this is inadequate pay. A survey of ten youth housing workers revealed the ways they struggle to afford housing. Some paid more than 30 per cent of their wage on housing costs. Others relied on income other than their youth housing worker salary to afford rental accommodation that included pay from a second job, drawing on credit and financial support from partners, family and friends. Most reported that they do not have sufficient income to save to enter home purchase. These findings resonate with secondary source aggregate data, which identifies that for almost a decade the pay of youth homelessness service workers in Victoria has not kept pace with average wage growth and rises in rents and house prices. Improving youth housing workers pay is recommended as a way to address their housing affordability concerns.
\end{abstract}

\section{Key words}

Youth housing workers

Housing affordability

Pay equity

\section{Introduction}

According to the Australian Federal Government's White Paper plan to reduce homelessness the pay and conditions of homelessness service workers are inadequate (Commonwealth of Australia, 2008). This observation took place in the context of significant problems with housing affordability in Australia (The Senate Select Committee on Housing Affordability in Australia, 2008). This study asks a somewhat paradoxical question, does the pay and conditions homelessness services workers receive put them at risk of housing affordability problems?

This question is important for a number of reasons. The White Paper identifies those who work with homeless people have a critical role to play in successfully achieving the paper's two 'headline goals'; to halve homelessness and offer supported accommodation to all rough sleepers who need it by 2020 (Commonwealth of Australia, 2008, p. viii). It is reasonable to expect those workers with the task of supporting people out of homelessness get paid enough to afford secure housing themselves. And if those who work with homeless people experience housing affordability problems it could undermine the delivery of the quality specialist services needed to achieve the 2020 targets. 
The majority of workers in the community sector are women and this research could also contribute to agendas interested in understanding and addressing the gender pay gap and women's experiences of housing. The study is particularly timely given the 'National Pay Equity Case', which could lead to significant increases to the wages of housing workers (Australian Services Union, 2009). Low wages are also identified as a reason it is difficult to attract and retain qualified, skilled, and capable homelessness service workers (Smith, 2010; Wright-Howie, 2008). This research connects with activities aimed at strengthening the youth and community sectors, such as the proposed National Workforce Development Strategy for homelessness services, which have the intention of addressing critical workforce issues in the homelessness services sector including inadequate wages and high staff turnover (Commonwealth of Australia, 2008).

To explore whether or not the pay of youth housing workers puts them at risk of housing affordability stress I compare secondary source aggregate material on the wages of youth homelessness service workers with research on housing affordability in Australia. I supplement this with the results from a survey of ten Victorian youth housing workers designed to establish whether their pay is enough to cover basics such as rental payments, the initial costs associated with purchase of a house, and mortgage repayments. According to Yates et al. (2007) housing affordability concerns can be measured in terms of people's subjective experience of managing their housing costs. The ways in which the interviewees experience, identify and negotiate housing affordability in their everyday lives is also presented. Along with relevant literature the youth housing worker's accounts provide a basis from which I articulate recommendations about how to address housing affordability problems for this cohort of workers.

\section{Literature review}

Chapman (2006) described the ways housing affordability stress is commonly measured. The first of these is paying over 30 percent of gross household income in housing cost. The second measure is not having sufficient income to save to enter home purchase. Thirdly housing affordability concerns are recognised as not having sufficient income to sustain housing payments. Finally, not having sufficient income after paying for housing to buy the basic necessities of life is an indicator of housing affordability stress. There are good reasons to believe youth homelessness service workers experience housing affordability problems. Anecdotal accounts from youth housing workers suggest this is the case (Bartlett, 2009; Lazzari, 2010).

Furthermore, the wages of Victorian youth homelessness services workers have fallen behind growth in incomes, rents and house prices and this could translate into housing affordability problems for these workers. Most youth housing workers are employed by the notfor-profit or community sector, and most workers in the community sector, including youth homelessness service workers, are paid according to rates of pay articulated in state-based Social and Community Services (SACS) Awards. The Victorian Council of Social Services (2008) argued wages in the Victorian community sector have not kept pace with inflation or average wage growth since at least 2003. As shown in Table 1, between 1999 to 2010 the SACS Victoria - Award rates of pay for the classification Youth Worker Class 3 Year 1 increased by 
just over 33 percent compared to an almost 65 percent increase to average full-time adult ordinary time earnings. Burke et al. (2007) also report rents have remained fairly consistent to increases in the consumer price index over time, while house prices have almost doubled in cost since the late 1990's. Table 1 indicates the extent to which increases to rent and house prices in Melbourne have exceeded youth worker wage rises. For example, from 1999 to 2010 the median rental for a two bedroom flat in Melbourne grew three times faster than the Youth Worker Class 3 Year 1 rate of pay. The median Melbourne house price rose at almost five times the rate of the youth worker wage over the same period. In other words secondary source aggregate data reveals the pay of youth homelessness service workers in Victoria has not kept pace with average wage growth and rises in rents and house prices. Burke et al. (2007) report housing stress can be as much a result of stagnant incomes as fluctuations in housing costs.

...it is not that rents have increased to excessive levels (they have remained relatively constant) that has created the affordability problem, but that incomes are too low and too uncertain (Burke, 2007, p. 11).

Yates et al. (2007, p. 9) add 'housing affordability problems tend to increase whenever housing costs rise faster than incomes'. As a result of stagnant and low incomes youth housing workers could struggle with housing affordability.

\section{Table 1}

Charting increases to wages, rents and house prices from 1999 to 2010

1999

2010

Percentage increase

Youth worker - Class

$\$ 640.80^{1}$

$\$ 856.68^{2}$

33.68

3 Year 1 - wage per

week

Average full-time

$\$ 753.70^{3}$

$\$ 1,243.10^{4}$

64.93

adult ordinary time

1 Victorian Employers' Chamber of Commerce and Industry (1999). September 1999.

2 Jobs Australia (2010). July 2010.

${ }^{3}$ Australian Bureau of Statistics (1999). August 1999.

${ }^{4}$ Australian Bureau of Statistics (2010). May 2010. 
earnings per week

Melbourne two

$\$ 165.00^{5}$

$\$ 340.00^{6}$

106.00

bedroom flat median

rent per week

Melbourne median

$\$ 230,500.00^{7}$

$\$ 601,500.00^{8}$

160.95

house price

\section{Methodology}

Face to face semi-structured individual interviews were conducted with ten randomly selected Victorian youth housing workers. Participants were recruited by placing notices in three youth and community sector electronic newsletters. Participation was voluntary. Participants were asked a series of questions relating to their current position of employment, their pay and conditions, and their housing costs and experiences. Drawing on Liamputtong (2009) and Walter (2006) the in-depth interviews aimed to elicit rich information from the respondents on their experience of managing their housing costs and such personal accounts are valuable for assessing housing affordability concerns (Yates et al., 2007). Following each interview a copy of the transcript was sent to the participant, who checked the accuracy of the data and made corrections.

The interview transcripts were analyzed using qualitative data analysis. The responses from the youth housing workers were examined and compared to identify common and exceptional or individual experience (Gay et al., 2005). During this process the material was collated into key categories and then compared with secondary source aggregate data as well as relevant literature on full-time adult ordinary time earnings and housing affordability problems (McMillan \& Schumacher, 2005).

${ }^{5}$ Real Estate Institute of Australia (1999). September 1999.

${ }^{6}$ Department of Human Services (2010). September 2010.

${ }^{7}$ Real Estate Institute of Australia (1999). September 1999.

${ }^{8}$ Real Estate Institute of Victoria (2011). December 2010. 


\section{Research findings}

A descriptive analysis of the interviews is provided. Collated data from the interviewees is compared with secondary source aggregate material and relevant literature where appropriate.

\section{Demographic information}

Five youth housing workers were aged between 24 and 30 years of age, three 31 to 40 , and two 41 to 50. The different ages of the participants is significant. Older workers are closer to retirement and are likely to be more concerned with housing and income security post work. On the other hand it is probable that younger workers are more interested in entering the housing market and securing an income that enables this.

Eight women and two men were interviewed. There are significantly more women than men working in the community sector and the gender difference of the cohort of youth housing workers who were interviewed reflects this.

Five participants had degree qualifications relevant to human service work including Bachelor Social Work, Bachelor Human Services, and Bachelor Social Science (Youth Work). Two of these interviewees had honors and another two had double degrees. The other five youth housing workers had relevant TAFE and VET certificates such as Diploma Youth Work, Diploma AOD work and Diploma Welfare Studies. Two of these interviewees had dual certificates.

\section{Position of employment and hours of work}

All the youth housing workers were employed by community sector organisations that work with young people who are homeless. Five participants worked in transitional housing, three had dual roles in transitional housing and crisis accommodation, one worked in a youth refuge and one an information and support role. Their position titles included 'youth housing support worker', 'residential youth worker' and 'youth support worker'.

Six youth housing workers had been employed in their current position for six to twelve months, while the remaining four participants had been in their current positions for eighteen months, four years, six years, and eights years respectively. While six of the youth housing workers had been employed for six to twelve months in their current position many reported they had worked in the community sector for significantly longer periods of time.

Seven youth housing workers were employed full-time (38 hours per week) and three were employed permanent part-time on 0.8 fraction of full-time work. Seven participants also worked Monday to Friday 9am to $5 \mathrm{pm}$ with time-in-lieu allowance provided for out-of-hours or overtime work. On the other hand three youth housing workers worked overnight and weekend shifts in youth residential or refuge settings. One interviewee did such shifts weekly, another did 
three weekend shifts per month, and the third was 'on-call', or would be contacted in case of an emergency out-of-hours, one week per month.

\section{Pay}

Nine youth housing workers were paid according to the SACS - Victoria - Award 2000 (Jobs Australia, 2010). The tenth interviewee was paid in accordance with an Enterprise Bargaining Agreement, in which the rates of pay aligned with the SACS - Victoria - Award 2000. All of the participants salary packaged, or salary sacrificed the maximum allowed fraction of their wage before income tax, which varied between 30 to 35 percent.

The basic hourly rate of pay before tax that the youth housing workers received ranged from $\$ 22$ per hour to $\$ 29.15$ per hour; the average was $\$ 24.28$ per hour, which converts to $\$ 922.64$ per week. The Australian Bureau of Statistics (2010) reported in May that average fulltime adult ordinary time earnings were $\$ 1,243.10$ per week before tax. In other words, in general the youth housing workers earned approximately $\$ 16,664$ less per year before tax than the average Australian worker. This puts the following comment from one of the youth housing workers into context.

On the wage I am on I am close to being eligible for public housing. I am only earning $\$ 5000$ over the income/asset level to be eligible.

Using the simple income tax calculator provided by the Australian Taxation Office (2010) the average take home pay after tax for workers paid the full-time adult ordinary time earnings is approximately $\$ 988$ per week. The youth housing worker's take home pay after tax ranged from $\$ 600$ to $\$ 950$ per week, which includes factoring in salary packaging. The average take home pay for the seven participants employed full-time was $\$ 833$ per week or $\$ 8,060$ less per year compared to the pay the average Australian worker takes home. Moreover, even with salary packaging and penalty rates of pay for out of hours, on-call and weekend work, the youth housing workers appeared to take home considerably less pay than the average Australian wage earner.

\section{Housing tenure, duration, location and structure}

Eight youth housing workers rented their dwelling, and two were living in a house they were purchasing and had mortgages. Given the high rates of home ownership in Australia the number of private renters among the cohort of youth housing workers was high. At the same time, Kryger (2009) reported rates of home ownership in Australia increase progressively with age and in light of the majority of respondents being less than forty years of age the high proportion of the sample in rental accommodation may not be significant.

Three participants had been living in their current accommodation for less than twelve months, two between twelve months to two years, three between two years to three years, and two for more than three years. 
Four youth housing workers were living in inner northern Melbourne suburbs, located less than $15 \mathrm{~km}$ from the Melbourne GPO. There was one interviewee living in the inner south, one in the inner west and one in the inner east, all less than $15 \mathrm{~km}$ from the Melbourne GPO. One participant was living in the outer west and the remaining two participants were living in the outer east, more than $15 \mathrm{~km}$ from the Melbourne GPO.

Three youth housing workers were single parents living with children. One participant was living with a partner and their child. Three interviewees were living in group households without children. Two were living with their partner without children. One participant lived alone. There are increasing numbers of Australians living in sole person households and affording to live alone may be out of reach for many who are paid youth housing worker wages. Flood and Baker (2010) also reported from 1996 to 2006 singles (aged 25 to 44), single parents (aged 25 to 44) and defacto couples experienced higher rates of home ownership. Seven of the respondents fit these categories, however only one is purchasing a home.

\section{Housing costs}

Figure 1

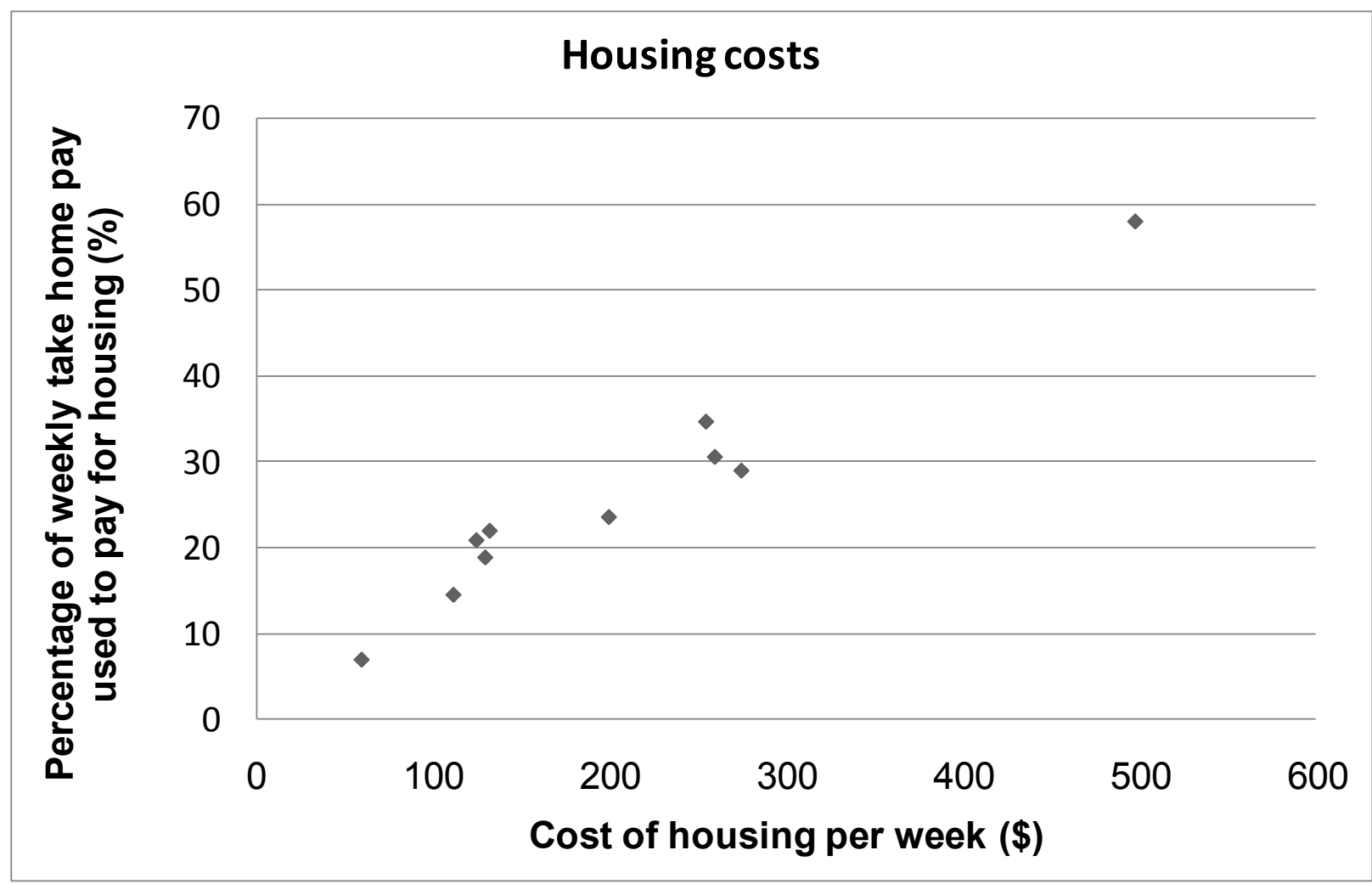


As shown in Figure 1, one youth housing worker paid less than $\$ 100$ per week on their housing. This interviewee was renting a house for $\$ 60$ per week from a family member, and the estimated market rental of this property is $\$ 250$ per week. Five participants paid between $\$ 101$ and $\$ 200$, three paid between $\$ 201$ and $\$ 300$, and one paid more than $\$ 301$ on housing costs.

Figure 1 also outlines the percentage of weekly take home pay the youth housing workers use to pay for their housing. This was less than 10 percent for one participant and for a further two interviewees it was between 11 and 20 percent. Four youth housing workers paid between 21 and 30 percent of their take home pay on their housing costs, and three pay more than 30 percent. Of particular concern are the four youth housing workers paying close to 30 percent or more of their take home pay on housing costs given this is a measure of housing affordability stress. Also of significance is that the housing workers take home pay includes salary packaging, and many mentioned that they would not be able to afford their current housing if salary packaging was not available.

The five youth housing workers with no children and sharing housing costs with partners or co-occupants were paying less than 30 percent of their take home pay on housing. Three of the interviewees with children and the youth housing worker living alone were paying more for their housing as well as a larger percent of their take home pay on housing costs compared to those sharing their housing costs with partners or co-occupants.

\section{Experiences of housing stress}

According to Yates et al. (2007) housing stress can be measured in terms of people's subjective experience of managing their housing costs. The youth housing workers were asked a series of questions to explore how they experience, identify and negotiate housing affordability in their everyday lives.

Nine youth housing workers believed they experienced housing stress. One described worrying about rent rises.

Every 6 months I live in fear the rent could go up, and if it goes up I just wouldn't survive.

Two youth housing workers were not on the lease of the rental properties where they lived, and one said 'I see not being on a lease as housing insecurity'. Another who was purchasing a home reported;

My housing is new so there are no maintenance costs at the moment. But what happens if something needs repair, I have no capacity to save for maintenance and repairs.

\section{Parity of wages with rising housing costs}

Yates et al. (2007, p. 9) identified 'housing affordability problems tend to increase whenever housing costs rise faster than incomes'. Eight of the interviewees said their youth housing worker wage had not kept pace with increases in their housing costs, as illustrated by this account. 
If I look back before I was in this rental property the cost of my housing would go up every 6 months whereas my wage was indexed annually, it only increased once per year. And according to another with a mortgage, 'since I took out the loan in December 2009 there have been 3 interest rate rises in the last 6 months, but no salary increases'.

Two of the interviewee's housing worker wages had kept pace with changes in the cost of their housing and this was because their housing costs had increased only marginally, not because their wage had increased in line with rising housing costs. One participant had a $\$ 5$ per week rent increase over the previous eighteen months; and the other only one rent increase in two and a half years.

\section{Struggling to pay for housing}

Three youth housing workers claimed they did not struggle to pay for their current housing. The explanations they gave for this were, 'I have only had a $\$ 5$ rent increase over the past eighteen months', 'I am a budget queen, I count every penny', and 'the landlord has only put up the rent once in two and a half years'.

Six youth housing workers also said they did not struggle to pay for their housing however the reasons they provided for this were concerning. Some prioritized rental or mortgage repayments over other expenses such as utility costs. For example one interviewee claimed, 'I just have to pay for the housing, to budget and manage the money. Sometimes bills have to wait, or I can't buy or do things'. Others spoke about experiencing financial stress, for example;

We experience financial stress, just without housing stress, talking about money puts a strain on our relationship.

Another relied on credit as a way to avoid struggles with housing costs.

Some months I have to dip into a flex-loan. I have to have a loan just to pay for rent and maintenance. I will pay off this loan at some point but I have been living like this for 2 years.

One interviewee reported they do struggle to pay for their housing, but they manage because, 'luckily I have a partner who will pick up the slack for me'.

\section{Reliance on other income for housing}

Seven participants were relying on other income than the pay they receive as a youth housing worker to afford their housing. Two youth housing workers supplemented their housing worker wage with income from a second job so they could afford rental accommodation. In other words, the take home pay they received from their youth housing worker position was not enough to cover their housing costs. The participant who lived alone explained their reason for getting a second job to afford their preferred housing.

I had to get a second job to retain the housing I have. I could have moved into share accommodation but I work with chaotic people all day so I want my own space. I want to go home and not have chaos or hear people's dramas 
The other five participants from this cohort claimed they would not be able to afford their housing without the financial contribution of partners or others they lived with. These youth housing workers were living in share accommodation with their partner or co-occupants and paying less than 30 percent of their take home youth housing worker pay on housing. One described that they were relying on a male partner, who earned significantly more than they did, to afford their housing.

I have to rely on my partner financially and I hate this, I've never had to do that before. If my relationship was to break down I don't like my chances of finding something else.

Three youth housing workers were not relying on other income to afford their housing. These three interviewees had children and would be in receipt of family tax benefit. However they did not indicate that this contributed directly towards their housing costs.

\section{Deprivation to pay for housing}

All of the youth housing workers claimed they went without something to afford their housing. Some said they missed out on having the social life they would prefer, could not go out with friends or eat out, and went without recreational and leisure activities such as holidays. One interviewee could not buy gifts for their children on special occasions such as birthdays or Christmas. Others said they went without having children or fostering, or could not afford having a pet, a car or a home phone. There were also reports of foregoing quality heating and not being able to afford further study. Some of the youth housing workers described that they were 'living week to week' and could not save money for retirement or a deposit to buy a home. Another interviewee mentioned they go without new furniture to pay for their housing.

I take young people with Transition to Independent Living Allowance, which is $\$ 1,500$, to buy items for their housing, and typically it is a new bed and a couch. I can't even afford this, and when I go with them to buy this stuff I know I am going to be going home to my couch I got from the side of the road.

Paradoxically workers assisting young people with housing may be more materially disadvantaged than the service users.

\section{Compromises and 'trade-offs' to pay for housing}

According to Yates et al. (2007, p. 5) 'many household pragmatically avoid severe affordability problems arising from housing stress by making trade-offs'. All of the interviewees reported making compromises and trade-offs to afford their housing. Three of the youth housing workers said they would prefer not to live with others in share households but they could not afford to live alone. Another said, 'I don't have the option to move. I am stuck where I am. I couldn't afford to move, I feel trapped there'.

A significant trade-off for many of the youth housing workers was to put up with faults with their housing rather than 'complain' to the landlord about required maintenance. One spoke

of enduring plumbing that did not work. 
We put up with the toilet not working and water not draining in the shower. This lasted for around 6 months. We put up with it because in the house we rent the rent could be higher, and the landlord eventually wants to demolish the house, and so we didn't want to complain in fear that the landlord might just choose to end the lease.

Another went without a functioning oven.

Our oven has been broken for a while. We have to compromise what we would prefer, like an oven that works, to maintain housing stability.

Two of the youth housing workers said the heating in the dwelling they rented 'doesn't work' and 'isn't effective'. Another interviewee, living with children, did not have a proper shower.

I don't complain for fear of the rent being put up. For example, the shower is just a

plastic hose, it's not a proper shower and it's coming off the shower wall.

Others spoke of trading off living in an area they would prefer to secure affordable rental accommodation. For some this meant 'having to move so far out of the city just to get something affordable'. It also resulted in some of the youth housing workers living a significant distance from their workplace, and according to one of the interviewees, 'I can't live near work. The drive to work is too much, two hours per day'. Another said;

I can't live close to the city. And this limits my work options. A lot of the jobs I would like to take I have to consider the cost of petrol and other costs. I have to live in an area far out of the city and that I don't like.

One of the youth housing workers purchasing a house has a child and described how they could only afford to buy a one bedroom apartment. This meant 'I choose to sleep on the couch in the living room and my daughter has the bedroom'.

\section{Aspiration for home ownership}

Eight youth housing workers wanted to buy a house. The reasons given for not purchasing were not earning enough and rising house prices. One illustrated the point by saying, 'we can't afford it on the wage I am getting and due to the cost of housing going up further and further'. Another said;

We thought we were (in a position to save a deposit) but we aren't at the moment because of the costs of living. What we were saving has gone on this. We also needed a second car because work is so far away and not accessible by public transport, and our housing is isolated and my partner needs a car.

Most of the interviewees claimed home ownership was out of reach and the explanation they all provided for this was the inadequacy of their youth housing worker wage. As a result of not being able to enter home purchase many spoke of resigning to live in rental accommodation for the long-term. A youth housing worker described this in another way, 'the wage I receive means we can't save for a deposit. I feel trapped in rental accommodation'. Another spoke of how they never anticipated rental accommodation would be their long term housing tenure.

When I was growing up I didn't think I would be living in rental accommodation when I was 30 , I thought I would have something decent by then. 
Only two youth housing workers yet to buy a house believed they were in a position to save for a deposit. However one participant said;

I am saving a bit, but to get a deposit it will probably take 20 years, and this is my partner and I saving.

Evidently they were a long way from achieving this aspiration.

\section{Strategies to buy a house}

Community sector workforce audits identified low salaries contribute significantly to difficulties in recruiting and retaining staff (Australian Council of Social Services, 2010; Productivity Commission, 2010). The eight youth housing workers yet to purchase a house claimed they would have to leave working in youth housing to afford to buy a home. One said they could afford home purchase 'by doing a different job with better pay. To be able to buy I house I will have to get out of youth housing'. According to another;

It is not just the wages at the moment but the lack of potential and lack of options in the community sector to earn more.

The point was further illustrated by the comment, 'I love this sector but I am not going to remain poor my whole life'. In other words not being able to purchase a house has implications for attracting and retaining homelessness service workers.

\section{Discussion}

The experiences of the youth housing workers interviewed for this study aligns with anecdotal accounts from youth homelessness service workers and the literature on community sector wages and housing affordability. Moreover, according to the youth housing workers the pay they received was less than average weekly wages and as a result they were vulnerable to housing affordability problems.

The youth housing worker's accounts of negotiating housing affordability also resonate with ways housing affordability problems are formally understood and measured. One way housing affordability stress is defined is when someone is paying over 30 percent of gross household income in housing cost, and three interviewees were doing just that.

Not having sufficient income to save to enter home purchase is another indicator of housing affordability problems. For the majority of the youth housing workers the pay they receive was not enough to cover the initial costs associated with the purchase of a house. Many described being 'trapped' in rental accommodation.

Wood and Ong (2010) argue the presence of young dependent children reduces the odds of escaping housing affordability stress by over 40 percent. Burke et al. (2007) also identify singles and sole parents and those living in private rental experience housing affordability problems more intensely compared to others. Among the sample interviewed for this study it was the youth housing workers with children or who were living alone that paid the largest percentage of their income on housing costs. Basically, those without other wage earning adults 
to share the cost of housing were in significant housing stress. The majority of interviewees were also renting and some believed this would be their long term housing tenure.

A further measure of housing affordability concerns is not having sufficient income to sustain housing payments. For some of the youth housing workers their youth housing worker wage was not adequate to cover their housing costs and they had to draw on income from a second job or relied on credit to afford rental accommodation. Many also reported relying on financial and other contributions from partners, families and housemates to meet their housing costs.

Chapman (2006) identifies housing affordability stress as not having sufficient income after paying for housing to buy the basic necessities of life. All of the youth housing workers made a range of substantial trade-offs and troubling compromises to afford their housing. Some of the youth housing workers experienced what Burke et al. (2007) refer to as 'little slack in the system', which made it difficult for them to meet unexpected costs or less frequent costs such as utility bills. Many of the interviewees also struggled to afford good quality housing and half provided examples of substandard plumbing, heating, and cooking facilities.

Another worrying finding was that two of the youth housing workers were not on a lease while living in shared rental accommodation and this does not meet the community standard for minimum accommodation. According to Chamberlain and MacKenzie (1992) the community standard for minimum accommodation that people can expect to achieve in contemporary society is a small rental flat with a bedroom, living room, kitchen and bathroom and an element of security of tenure provided by a lease.

Completing three, four or even five years of tertiary education did not provide the youth housing workers the credentials needed to secure employment paying a wage that would circumvent housing affordability problems. Healy and Lonne (2010) also identified those working in helping professions have limited capacity to increase their income whilst remaining in direct service work. The interviewees who had worked in youth housing positions for four, six or eight years did not receive on-going salary increases that ensured sufficient income to avoid housing affordability concerns. Three of the youth housing workers were also paid for out-ofhours and overtime work; however this additional income to the basic rate of pay did not enable the workers to steer clear of struggles with housing affordability.

The findings also assist with understanding implications of the gender pay gap. Lower pay in the female dominated community services industry contributed to the interviewees housing affordability struggles. Half of the interviewees also had to rely on the income of others to afford their housing, and it was the youth housing workers who did not have the financial contribution of partners or others that paid more on housing. Moreover, is the lower female wage predicated on the assumption of another breadwinner?

\section{Recommendations}

\section{Further research}


Some worrying trends emerged that warrant turning this pilot investigation into a larger research project that draws on a representative sample of youth housing workers in different jurisdictions. The impacts of workers' housing problems on the quality of homelessness services is also worthy of further investigation. It would also be useful to explore the experiences of other community sector workers given most are paid according to SACS Awards.

A National Homelessness Research Agenda is another initiative of the Federal Government's White Paper plan to reduce homelessness (Department of Families, Housing, Community Services and Indigenous Affairs, 2009). Research interested in strengthening the homelessness workforce and improving wages and conditions should be a priority.

There is also a need for further research to identify whether improved wages that could result from the Equal Remuneration case, if successful, will make up for years of neglect to community sector worker's pay. Such an investigation could explore whether the potential pay increases will be sufficient for youth housing worker's wages to catch up to the rises in rents, house prices, the cost of living, and average wage growth that have taken place over the last decade.

\section{Homelessness workforce development strategy, National Partnership Agreements and Implementation Plans}

If the homelessness services workforce strategy is interested in addressing critical workforce issues in the sector such as problems with recruitment and retention of staff then improving wages and conditions should be a priority. However just what the strategy could achieve on these fronts is unclear given the responsibility for pay and conditions rests with State and Territory Governments. At the same time two Youth Homelessness Action Plans in Victoria are examples of a State Government identifying the need to increase the capacity of the homelessness service sector to improve service provision but not delivering improvements to pay and conditions for youth housing workers (Department of Human Services, 2006).

An alternative could be Federal, State and Territory Governments prioritizing the improvement of wages and conditions in National Partnership Agreements and Implementation Plans (Department of Families, Housing, Community Services and Indigenous Affairs, 2010).

\section{Invest in decent wages for youth housing workers}

The Federal Labor Government recently demonstrated a willingness and capacity to invest in addressing homelessness, increasing spending by $\$ 1.2$ billion over five years from 2008-09 (Commonwealth of Australia, 2008). The government should build on these commitments by delivering improvements to youth housing workers pay.

There are other solutions that could address the housing affordability problems experienced by youth housing workers who participated in this study. For example improving the supply of well-located housing stock at the low-cost end could make a difference. However the 
youth housing workers would argue that improving their pay and conditions would be a good place to start.

\section{Conclusion}

This article makes a case that the pay youth homelessness services workers in Victoria, Australia, receive puts them at risk of housing affordability concerns. On average the wages of youth housing workers are considerably less than ordinary time full-time earnings and have not kept pace with increases to the cost of living, rents and house prices. The ways youth housing workers experience housing affordability stress as a result of inadequate pay were identified. Further research was suggested to identify the extent of the problems as well as the ways in which worker's housing insecurity impacts on the quality and outcomes of services provided to young homeless people.

Improving youth housing workers pay could assist with addressing critical workforce issues in the homelessness service sector as well as contribute towards securing the qualified, skilled and capable workforce needed to achieve the Federal Government's White Paper plan to reduce homelessness. Moreover if the government is serious about reducing homelessness it would ensure those workers with the task of supporting people out of homelessness are not at risk of housing affordability problems.

Youth housing workers should get paid enough to afford the basic necessities of life including quality housing. Improving the pay for youth housing workers could be realized as a result of the Equal Remuneration case. Other suggestions included the strategic use of National Partnership Agreements and Implementation Plans, and the Federal Government building on its commitments to address homelessness and invest directly in youth housing worker wages.

\section{References}

Australian Bureau of Statistics. (2010). 6302.0 - Average weekly earnings Australia, May 2010. Retrieved 15 August 2010, from http://www.abs.gov.au/ausstats/abs@.nsf/mf/6302.0

Australian Bureau of Statistics. (1999). 6302.2: Average weekly earnings, States and Australia, August 1999. Retrieved 11 February 2011, from http://www.ausstats.abs.gov.au/Ausstats/subscriber.nsf/0/E188FE63887BD8D3CA2568BA002E 4567/\$File/63020_Aug\%201999.pdf

Australian Council of Social Services. (2010). Australian community sector survey: Report 2010 Volume 1 - National. Strawberry Hills, NSW: Australian Council of Social Services.

Australian Services Union. (2009). Care Professional, 1(4).

Australian Taxation Office. (2010). Simple Tax Calculator. Retrieved 15 August 2010, from http://www.ato.gov.au/individuals/content.asp?doc=/content/23519.htm 
Bartlett, M. (2009). Low-paid care workers no better off than clients. The Age, 11 November.

Burke, T., Pinnegar, S., Phibbs, P., Neske, C., Gabriel, M., Ralston, L. \& Ruming, K. (2007). Experiencing the housing affordability problem: blocked aspirations, trade-offs and financial hardships. Melbourne: Australian Housing and Urban Research Institute.

Chamberlain, C. \& MacKenzie, D. (1992). Understanding contemporary homelessness: Issues of definition and meaning. Australian Journal of Social Issues, 27(4), 274-297.

Chapman, P. (2006). Housing affordability in Australia. AHURI Research and Policy Bulletin, 68 .

Commonwealth of Australia. (2008). The Road Home: A National Approach to Reducing Homelessness. Canberra: Commonwealth of Australia.

Department of Families, Housing, Community Services and Indigenous Affairs. (2010). National partnership agreements on homelessness. Retrieved 15 August 2010, from http://www.fahcsia.gov.au/sa/housing/progserv/homelessness/national partnership agreement/P ages/NPAHomelessness.aspx

Department of Families, Housing, Community Services and Indigenous Affairs. (2009). National homelessness research agenda 2009-2013. Canberra: Commonwealth of Australia.

Department of Human Services. (2010). Rental report: September quarter 2010. Melbourne: Victorian Government Department of Human Services.

Department of Human Services. (2006). Creating connections: Youth homelessness action plan stage 2: 2006-2010. Melbourne: Victorian Government Department of Human Services.

Flood, J. \& Baker, E. (2010). Housing implications of economic, social and spatial change: AHURI final report no. 150. Melbourne: Australian Housing and Urban Research Institute.

Gay, L., Mills, G., \& Airasian, P. (2005). Educational research: Competencies for analysis and applications. $8^{\text {th }}$ edition. New York: Prentice Hall.

Healy, K. \& Lonne, B. (2010). The social work and human services workforce: Report from a national study of education, training and workforce needs. Strawberry Hills, NSW: Australian Learning and Teaching Council.

Jobs Australia. (2010). Social, Community, Home Care and Disability Services Industry Award 2010, Social and Community Services (Victoria) Award 2000: Transitional pay table (Federal). Retrieved 15 August 2010, from http://www.ja.com.au/attachments/14453/SACS\%20VIC\%20Transitional.pdf 
Kryger, T. (2009). Home ownership in Australia - date and trends. Canberra: Department of Parliamentary Services.

Lazzari, J. (2010). Making it home youth conference 2009: Report. Collingwood: Council to Homeless Persons.

Liamputtong, P. (2009). Qualitative research methods. $3^{\text {rd }}$ edition. South Melbourne: Oxford University Press.

McMillan, J., \& Schumacher, S. (2005). Research in education: Evidence-based inquiry. $6^{\text {th }}$ edition. Boston, MA: Allyn \& Bacon.

Productivity Commission. (2010). Contribution of the not-for-profit sector: Productivity Commission research report. Canberra: Commonwealth of Australia.

Real Estate Institute of Australia. (1999). Market facts: September 1999. Deakin, ACT: Real Estate Institute of Australia.

Real Estate Institute of Victoria. (2011). Trend chart: Current median house price: $\$ 601,500$. Retrieved 11 February 2011, from http://data1.reiv.com.au/trendchart/

Smith, S. (2010). Gathering around the table: Challenges to the successful implementation of the White Paper. Parity, 23(2), 14-15.

The Senate Select Committee on Housing Affordability in Australia. (2008). A good house is hard to find: Housing affordability in Australia. Canberra: Commonwealth of Australia.

Victorian Council of Social Services. (2008). NGO price index and CPI changes. Retrieved 15 August 2010, from www.vcoss.org.au/documents/VCOSS\%20docs/Sector\%20devtsustainability/Background $\% 20$ Paper $\% 20-\% 20 \mathrm{CPI} \% 20$ changes.doc

Victorian Employers' Chamber of Commerce and Industry. (1999). Social and Community Services (Interim) Award 19995: PLF0095/SM - 1 September 1995, No. 3 of 1999. Hawthorn: Victorian Employers' Chamber of Commerce and Industry.

Walter, M. (ed.). (2006). Social research methods: An Australian perspective. South Melbourne: Oxford.

Wood, G. \& Ong, R. (2010). How long does housing affordability stress last?. Melbourne: Australian Housing and Urban Research Institute.

Wright-Howie, D. (2008). Dear Mr Rudd, If we really want to end homelessness .... Future directions to address homelessness in Australia. Collingwood: Council to Homeless Persons. 
Yates, J., Milligan, V., Berry, M., Burke, T., Gabriel, M., Phibbs, P., Pinnegar, S.\& Randolph, B. (2007). Housing affordability: A $21^{\text {st }}$ century problem. Melbourne: Australian Housing and Urban Research Institute. 